\title{
Retrospective: Acute Toxicity of Priority Pollutants
}

\author{
Gerald A. LeBlanc ${ }^{1}$
}

Received: 13 June 2016/ Accepted: 16 June 2016/Published online: 22 June 2016

(C) Springer Science+Business Media New York 2016

Under the 1972 Federal Water Pollution Control Act Amendments, the US Environmental Protection Agency (EPA) was required to publish a list of toxic pollutants and propose effluent discharge standards for these pollutants within 90 days of listing. This mandate proved challenging for the EPA as the toxicity of many of the chemicals identified as "priority pollutants" was largely unknown. EPA defaulted on the mandate and was promptly sued by the National Resources Defense Council. The result was a court-supervised consent decree under which EPA was required to provide a basic assessment of the toxicity of these materials to aquatic organisms followed by the promulgation of standards.

I was a fledgling toxicologist in the late 1970s, working for the lab that was awarded the EPA contract to evaluate the acute toxicity of selected priority pollutants to daphnids (Daphnia magna). The result was a compendium of the acute toxicity, defined by 24- and 48-LC50 values, of 84 chemicals. EPA approved the publication of the data resulting in the Bulletin of Environmental Contamination and Toxicology article, "Acute toxicity of priority pollutants to water flea (Daphnia magna)" (LeBlanc 1980), the 8th most cited paper in the Bulletin.

Among the chemical classes evaluated were chlorobenzenes, chloroethanes, chlorophenols, metals, aromatic and aliphatic hydrocarbons, phthalate esters, chloropropanes, and chloroethylenes. The popularity of the article does not stem from its innovation, because standard EPA methods were used to assess acute toxicity. Rather, the article has

Gerald A. LeBlanc

Gerald_leblanc@ncsu.edu

1 Department of Biological Sciences, North Carolina State University, Raleigh, NC 27695-7633, USA and continues to serve as a resource on the acute toxicity of numerous, diverse chemicals.

Results revealed that most of the chlorobenzenes, chlorophenols, and metal salts evaluated were highly toxic to daphnids ( $48 \mathrm{~h} \mathrm{LC} 50<1.0 \mathrm{mg} / \mathrm{L}$ ) using the toxicity ranking system provided by the National Research Council (NRC 2014). Most lower weight phthalate esters were toxic (48 h LC50 1.0-10 mg/L), while compounds including fluoride, benzene, fluoranthene, toluene, and barium proved to have low acute toxicity ( $48 \mathrm{~h} \mathrm{LC50}>100 \mathrm{mg} / \mathrm{L}$ ).

This study is most commonly cited in works involving the hazard characterization of one or more of the compounds evaluated. However, results also have been used in other applications including comparative assessments of test methods (Ribo and Kaiser 1983; Qureshi et al. 1982), comparative assessments of test species (Pollino and Holdway 1999; Toussaint et al. 1995), and the establishment of quantitative structure-activity relationships or QSARs (Bobra et al. 1983; Bobra et al. 1985; Devillers et al. 1987).

I and colleagues subsequently published a companion paper in the Bulletin titled "Acute toxicity of priority pollutants to bluegill (Lepomis macrochirus)" (Buccafusco et al. 1981). This publication ranks as the 25th most cited paper in the Bulletin. These two papers along with additional data from other sources allowed me to publish a paper on interspecies relationships in acute toxicity of chemicals (LeBlanc 1984) which also has been cited over 100 times.

These papers served their intended purpose well: to provide data in support of the establishment of discharge standards for a group of relevant industrial chemicals. Yet, these papers continue to be cited over 30 years after publication. As more contemporary issues are pursued such as mechanistic toxicology, mixtures toxicology, and hazard 
modeling, the basic knowledge of the acute toxicity of chemicals provided in these publications will continue to be of value.

\section{References}

Bobra A, Shiu WY, Mackay D (1983) Acute toxicity of fresh and weathered crude oils to Daphnia magna. Chemosphere 12:1137-1149

Bobra A, Shiu YS, Mackay D (1985) Quantitative structure-activity relationships for the acute toxicity of chlorobenzenes to Daphnia magna. Environ Toxicol Chem 4:297-305

Buccafusco RJ, Ells SJ, LeBlanc GA (1981) Acute toxicity of priority pollutants to bluegill (Lepomis macrochirus). Bull Environ Contam Toxicol 26:446-452

Devillers J, Chambon P, Zakarya D, Chastrette M, Chambon R (1987) A predictive structure-toxicity model with Daphnia magna. Chemosphere 16:1149-1163

LeBlanc GA (1980) Acute toxicity of priority pollutants to water flea (Daphnia magna). Bull Environ Contam Toxicol 24:684-691
LeBlanc GA (1984) Interspecies relationships in acute toxicity of chemicals to aquatic organisms. Environ Toxicol Chem 3:47-60

National Research Council (2014) A framework to guide selection of chemical alternatives. The National Academies Press, Washington, DC

Pollino CA, Holdway DA (1999) Potential of two Hydra species as standard toxicity test animals. Ecotoxicol Environ Saf 43:309-316

Qureshi AA, Flood KW, Thompson SR, Janhurst SM, Inniss CS, Rokosh DA (1982) Comparison of a luminescent bacterial tests with other bioassays for determining toxicity of pure compounds and complex effluents. In: Pearson JG, Foster RB, Bishop WE (eds) Aquatic toxicology and hazard assessment, 5th conference, ASTM STP 766. American Society for Testing and Materials, pp 179-195

Ribo JM, Kaiser KLE (1983) Effects of selected chemicals to photoluminescent bacteria and their correlations with acute and sublethal effects on other organisms. Chemosphere 12:1421-1442

Toussaint MW, Shedd TR, van der Schalie WH, Leather GR (1995) A comparison of standard acute toxicity tests with rapid-screening toxicity tests. Environ Toxicol Chem 14:907-915 